\title{
People v. Calloway: A Restriction of Remedies for Broken Plea Bargains
}

In People v. Calloway, ${ }^{1}$ the California Supreme Court denied specific performance of a plea bargain breached by the trial judge to a criminal defendant who had relied upon the bargain by serving time in state prison. The Calloway court affirmed earlier holdings that specific performance of plea bargams will not be allowed absent very special circumstances, and strictly interpreted this doctrine. ${ }^{2}$ As a result, the defendant's remedy for a broken plea bargain will in most cases be limited to withdrawal of his guilty plea.

This Note argues that the unique facts of the Calloway case justified specific performance of the plea bargain under the special circumstances doctrine, and that the court could have used the case to articulate a standard for future applications of the doctrine. Part I summarizes the facts of the case, the majority holding, and the dissentmg opinion. Part II examines the law which governed plea bargains before the Calloway decision. ${ }^{3}$ Part III argues that the court used incorrect criteria in deciding whether special circunistances existed in Calloway's case. It further argues that the decision imposes an undesirable rigidity on the granting of remedies for breached plea bargains, and threatens public perceptions of judicial integrity. The Note concludes by suggesting that the legislature should solve the problems $\mathrm{Cal}$ loway creates, and should set forth specific rights for defendants offered plea bargains by judges.

I

The CAse

\section{A. The Facts}

Defendant Willie Calloway was charged with several violations of the terms of his probation. In August 1979, he agreed to plead guilty to some of these violations, and to return to state prison for up to 90 days

1. 29 Cal. 3d 666, 631 P.2d 30, 175 Cal. Rptr. 596 (1981) (4-3 decision).

2. Id. at 671,631 P.2d at $32,175 \mathrm{Cal}$. Rptr. at 598 (quoting People v. Kaanehe, 19 Cal. 3d 1, 13, 559 P.2d 1028, 1036, 136 Cal. Rptr. 409, 417 (1977)).

3. For an extensive coverage of plea bargaining's history, practice and procedure, see $13 \mathrm{~L}$. \& Soc'Y REv. 185 (1979) (special issue devoted entirely to plea bargaining). 
of diagnostic confinement. ${ }^{4}$ During Calloway's confinement, prison officials were to prepare a diagnostic report, after which Calloway was to return to court for sentencing. The trial judge explicitly told Calloway that he would not be sentenced to state prison after his release from confinement. ${ }^{5}$

At the time of this agreement, the trial judge had access to probation reports which recommended that Calloway be sentenced to state prison. This recommendation was based on Calloway's history of drug and alcohol abuse, his serious psychiatric problems, his continued assaultive behavior, and his general failure to cooperate with his probation officers. Calloway's 90-day confinement resulted in a more detailed evaluation which also indicated that he was both homicidal and suicidal. 6

When Calloway returned from confinement, the same judge who made the plea bargain agreement sentenced him to two years in state prison, with a 374-day credit for good conduct and time already served. ${ }^{7}$ At the time of sentencing, neither the prosecution nor the defense pointed out that the state prison sentence was contrary to the terms of the plea bargam. One week later, Calloway wrote to the trial judge, remmding him of the bargam and requesting a new sentencing hearing. The judge treated this letter as an ex parte request for rehearing and denied it.

\section{B. The Opinions}

The California Supreme Court vacated the decision, but permitted Calloway only to withdraw his admission of probation violation and to enter a new plea to that charge. The court ruled that the trial judge had not made a bargain with Calloway, but had only approved of a bargain made between the defendant and the prosecuting attoruey. ${ }^{8}$ It stated

4. Prior to the hearing, Calloway had been free on his own recognizance. $29 \mathrm{Cal} .3 \mathrm{~d}$ at 679 , 631 P.2d at 37, $175 \mathrm{Cal}$. Rptr. at 603 (Bird, C.J., dissenting).

5. Id. at $675,631 \mathrm{P} .2 \mathrm{~d}$ at $34,175 \mathrm{Cal}$. Rptr. at 600 .

6. The Diagnostic Report is reproduced in an appendix to Defendant's Supplemental Petition for Writ of Habeas Corpus, People v. Calloway, Crim. Nos. 37038, 37113 (2d Dist. Div. One filed Apr. 18, 1980) (on file with the Clerk of the California Supreme Court).

At a judge's request, a probation report is prepared prior to sentencing, and can be supplemented with periodic progress reports. The probation report contains information on a defendant's background and criminal history, if any. A diagnostic report differs from a probation report in that it is a medical report, usually in letter form, which primarily examines the defendant's psychological stability. Telephone conversation with James Gartland, Unit Supervisor, Adult Supervision, Alameda County Probation Dept., (Feb. 15, 1982).

7. The factors which the judge considered in deciding to send Calloway to state prison despite the plea bargain are not indicated by the record.

8. 29 Cal. 3d at 672-73, 631 P.2d at 33, 175 Cal. Rptr. at 599. Under Cal. Penal Code $\S 1192.5$ (West Supp. 1981), a judge may at any time withdraw his approval of a prosecutor's bargain, in which case the defendant may withdraw his guilty plea. 
that specific performance of a plea bargain must be strictly limited because a defendant and prosecutor should not be able to bind a trial court, which is required to weigh the presentence report and exercise its customary sentencing discretion. ${ }^{9}$ While special circuinstances would justify specific performance, the court apparently considered that Calloway's 90-day mcarceration in reliance on the bargain was not a special circumstance. ${ }^{10}$ Thus, it held only that the 90 days could be credit for time served if Calloway withdrew his guilty plea and was later convicted. ${ }^{11}$ Finally, the court noted that while the United States Supreine Court had guaranteed a victim of a broken plea bargain a right to a remedy, it had left the form of the remedy to the discretion of the state courts. $^{12}$

In dissent, Chief Justice Bird ${ }^{13}$ argued that the trial judge had not merely approved a bargain between prosecutor and defendant, but had in fact "made an express personal commitment not to send [Calloway] to state prison." 14 Her dissent argued that this commitment was the primary inducement for Calloway's admission of guilt, and that Callo-

9. 29 Cal. 3d at 671,631 P.2d at 32, 175 Cal. Rptr. at 598 (citing People v. Kaanehe, 19 Cal. 3d at 13-14, 559 P.2d at 1037, $136 \mathrm{Cal}$. Rptr. at 418). The court uoted that in cases such as this one, "ordering specific performance would force the court to impose a sentence it expressly rejected as inappropriate." 29 Cal. 3d at 671, 631 P.2d at 32, 175 Cal. Rptr. at 598.

10. Id. at 671-73, 631 P.2d at 32-33, 175 Cal. Rptr. at 598-99 (citing People v. Kaanehe, 19 Cal. $3 d$ at 13, 559 P.2d at 1036, 136 Cal. Rptr. at 417$)$.

11. Id at $673,631 \mathrm{P} .2 \mathrm{~d}$ at $33,175 \mathrm{Cal}$. Rptr. at 599-600. The court did not discuss whether this remedy would be adequate if the defendant were not sentenced to prison on retrial. See infra text accompanying notes $70-74$.

12. $29 \mathrm{Cal}$. 3d at 673,631 P.2d at $33,175 \mathrm{Cal}$. Rptr. at 599 (citing Santobello v. New York, 404 U.S. 257, 262 (1971) (4-3 decisiou)).

13. Justices Newman and Woods joined the dissent.

14. $29 \mathrm{Cal}$. 3d at 673-74, 631 P.2d at 34, $175 \mathrm{Cal}$. Rptr. at 600 (Bird, C.J., dissenting). The text of the interchange between Calloway and the trial court seems to support this:

"THE COURT: Do you understand that if you admit that you are in violation of probation ... that the court will at this time sentence you to a diagnostic study which will be somewhere between 45 and 90 days in the state prison systein ... ? Do you understand that, sir?

"THE DEFENDANT: Yes, sir.

"THE COURT: And I will receive a report . . . at the end of [the] diagnosis. You will be brought back to this court at which time a decision will be made as to whether or not to reinstate you on probation or to inake soine other disposition.

"My agreement on the record between the District Attorney and your attorney is that I will not sentence you to state prison when you return. I will either sentence you to the county jail, put you back ou probation, perhaps terminate the probation completely on this case, allow you to have probation on your municipal court case to Judge Jakes, change the couditions of probation. I am really not telling you what I am going to do, but I am making a commitment that you will not be sentenced to state prison. Do you understand that, sir?

"THE DEFENDANT: Yes.

"THE COURT: Do you understand that you will be in custody up to 90 days and perhaps eveu some period of time after that when you return?

"THE DEFENDANT: (Nods head.)"

Id. at 675, 631 P.2d at 34-35, 175 Cal. Rptr. at 600-601 (Bird, C.J., dissenting) (einphasis added in opinion). 
way only had agreed to accept 90 days of diagnostic confinement in rehance upon this commitment. The dissent stated that because the trial court had received no new information on Calloway between the time of the bargain and the November sentencing hearmg, ${ }^{15}$ there was no justification for the judge's repudiation of the bargain.

The dissent also argued that because Calloway detrimentally rehed im good faith in the judge's promise, and because withdrawal of the plea would not have adequately compensated Calloway for the harm he suffered due to the judge's breach, special circumstances justified specific performance of the agreement. ${ }^{16}$ The dissent concluded that because the integrity of the judiciary and of the administration of criminal justice were imphicated, "[t]he unconditional commitments of the trial judge in this case should be honored."17

\section{II \\ LEGAL BACKGROUND \\ A. Validity of Plea Bargains}

In Brady v. United States, ${ }^{18}$ the United States Supreme Court vahdated the use of plea bargaining in the American judicial system. Acknowledging the prevalence of guilty pleas in American courts, ${ }^{19}$ the Brady Court observed that defendants who plead guilty benefit by incurring lesser penalties than they would face if they were found guilty after a trial. ${ }^{20}$ Brady also acknowledged that plea bargains allow the state to conserve its overburdened judicial and prosecutorial resources. $^{21}$ In light of these circumstances, the Brady Court concluded

15. Id at 676,631 P.2d at 35, 175 Cal. Rptr. at 601 . At the time of the plea bargain, the trial judge agreed not to send the defendant to state prison even though fonr supplementary reports, each recommending that Calloway's probation be revoked and that a prison sentence be imposed, were available to him. Id.

16. Id. at 679,631 P.2d at 37,175 Cal. Rptr. at 603.

17. Id. at 680,631 P.2d at 38,175 Cal. Rptr. at 604 .

18. 397 U.S. 742 (1970).

19. The Court estimated that more than $75 \%$ of all criminal convictions are the result of guilty pleas. Id. at 752 \& n.10. See, e.g. ABA Project on Minimum Standards for Criminal Justice, Standards Relating to Pleas of Gullty 60 (1967); D. Newman, Conviction: The DETERMINATION OF GUILT OR lNNOCENCE WiThout TRIAL 3 (1966); see also In re Hawley, 67 Cal. 2d 824, 828 \& n.1, 433 P.2d 919, 921 \& n.1, 63 Cal. Rptr. 831, 833 \& n.1 (1967) (in fiscal year 1965-66, 69\% of criminal cases in California superior courts were disposed of before trial).

20. 397 U.S. at 752.

21. Id. See also Santobello v. New York, 404 U.S. 257, 260-61 (1971) (4-3 decision). The desire to reduce backlogs sometimes results in what has been termed "disposition rate rivalry," in which the rapid disposition of criminal cases becomes a primary consideration of the plea bargaining system. See Alschuler, The Trial Judge's Role in Plea Bargaining, 76 Colum. L. REv. 1059,1100 (1976) (quoting a Chicago prosecutor's observation that “around here, a judge's worth is measured by the number of cases that he can move, and it does not seen to matter how he moves them"). 
that even though plea bargains potentially threaten the fifth amendinent privilege against self-incrimination and the sixth amendment right to a jury trial, extending such a benefit to a defendant who extends a benefit to the state in return does not violate the Constitution. ${ }^{22}$

Noting the constitutional dangers posed by plea bargains, the Brady Court established procedural safeguards to protect a defendant's rights. Under Brady, a valid guilty plea inust be both voluntary and intelligent. A plea is only voluntary if it is not coinpelled or coerced froin the defendant. Fear of a more severe penalty after a trial than is offered in the plea bargain, however, is not compulsion. ${ }^{23}$ A plea is intelligent if a defendant enters it with a full undcrstandimg of the charges against him and the possible consequences of the plea. ${ }^{24}$

A few nonths after Brady, the California Legislature enacted Penal Code section 1192.5, codifying the procedural aspects of plea bargaining in felony cases. The statute provides that if a guilty plea is accepted by the prosecution and approved by the court, the defendant cannot be given a inore severe sentence than that specified in the plea. Before approving the bargain, the court must satisfy itself that the plea is freely and voluntarily made, and must inforn the defendant that the court's approval is not binding on the trial judge. Finally, the statute provides that if the court withdraws its approval, the defendant may im turn withdraw his guilty plea. ${ }^{25}$

The California Supreme Court held plea bargaims valid in People v. West. ${ }^{26}$ West acknowledged, as did Brady, the acceptance of plea bargaining in American criminal procedure and its benefits to the state and the defendant. ${ }^{27}$ In addition, the court noted that plea bargaining advances the interests of justice by permitting the courts to treat the defendant as an individual and to adapt the punishment to the facts of the particular offense. ${ }^{28}$ Finally, the court, recognizing that the previous secretiveness of the plea bargaining process threatened the orderly administration of criminal law, provided that the bargain and its ternis be on record and disclosed to the trial court prior to sentencing. ${ }^{29}$

22. 397 U.S. at 753.

23. Id. at 751 .

24. Id. at $748 \&$ n.6.

25. Cal. Penal Code $\& 1192.5$ (West Supp. 1981). See People v. Delles, 69 Cal. 2d 906, 447 P.2d 629, 73 Cal. Rptr. 339 (1969).

26. 3 Cal. 3d 595, 477 P.29 409, 91 Cal. Rptr. 385 (1970).

27. Id. at 604-05, 477 P.2d at 413-14, 91 Cal. Rptr. at 389-90.

28. Id. at 605,477 P.2d at 414,91 Cal. Rptr. at 390 . Cf. Brady v. United States, 397 U.S. 742,753 (1970) (noting that failure to sanction plea bargaining "would require the States and Federal Government to forbid guilty pleas altogether, to provide a single invariable penalty for each crime . . . or to place the sentencing function in a separate authority having no knowledge of the unanner in which the conviction in each case was obtained").

29. The West court observed that the greatest danger of off the record sub rosa plea bargain- 


\section{B. Remedies for Broken Plea Bargains}

In Santobello v. New York, ${ }^{30}$ the United States Supreme Court recognized a defendant's constitutional right to a remedy for a prosecutor's breach of a valid plea bargam. In Santobello, the defendant pleaded guilty in exchange for the prosecutor's promise to make no recommendation to the court regarding sentencing. The prosecutor, however, was later replaced, and the new prosecutor recommended that Santobello be given the maximum sentence possible, in violation of his predecessor's agreement. The trial judge said he had not been influenced by the recommendation, but nonetheless gave Santobello the maximum sentence. ${ }^{31}$

The Court vacated the conviction and held that when a guilty plea is induced by a prosecutor's promise or agreement, the promise or agreement must be fulfilled. ${ }^{32}$ It emphasized that the legitimacy of plea bargaming is based on fairness in securing agreement between a defendant and the prosecution. ${ }^{33}$ The Santobello Court recognized that the appropriate remedy for breach would vary according to the circumstances of each case. ${ }^{34}$ It did not, however, specify what forn of relief would be available to defendants whose plea bargains are breached, nor did it offer guidelines to state courts faced with the necessity of choosing a remedy. Instead, the Court felt that the state courts could better decide whether specific perfornnance or withdrawal of the guilty plea was the inore appropriate remedy in a particular case. ${ }^{35}$

ing lies in its secretiveness, as the trial record will not reveal an unkept plea bargain or a plea induced by coercion or improper promises. 3 Cal. 3d at 609 \& n.12, 477 P.2d at 417 \& n.12, 91 Cal. Rptr. at 393 \& n.12.

30. 404 U.S. 257 (1971) (4-3 decision). Although this is the leading United States Supreme Court case on plea bargaining, soine states lave questioned the binding effect of a four to three Supreine Court decision on a state court, see, e.g., Roofing Wholesale Co. v. Palmer, 108 Ariz. 508, 512, 502 P.2d 1327, 1331 (1972), and may thus be less inclimed to follow Santobello than others. The California courts, lowever, lave utilized four to three Supreme Court decisions without confronting the issue of binding effect. See, e.g., Connolly Dev., Inc. v. Superior Court, 17 Cal. 3d 803, 817, 553 P.2d 637, 646, 132 Cal. Rptr. 477, 486, appeal dismissed, 429 U.S. 1056 (1976). See also Note, Constitutional Law-Supremacy Clause-State Court, 86 HARv. L. REv. $1307,1312,1313$ (1973) (arguing that "[a] state court lias 'no right' to question the authority of the Supreine Court when a majority of a legally constituted quorum of that body has rendered a decision . ..." and that "[a]lthough the Court has not exphicitly resolved the issue . . . its practice of handing down such decisions and recognizing their precedential value must be taken as an indication that they constitute authoritative and binding statements of law . . . ").

31. 404 U.S. at $259-60$.

32. Id. at 262. The Court also held that the change of prosecutors had no bearing on the defendant's right to a reinedy, noting that "the staff lawyers in a prosecutor's office have the burden of 'letting the left land know what the right hand is doing' or lias done." Id.

33. Id. at 261 .

34. Id. at 262.

35. Id. at 263. By allowing the state court to decide whether to enforce the bargain or set it aside, the Santobello Court seemed to dilute the force of its earher statement that an agreement that is part of the induceinent for a plea "must be fulfilled." Id. at 262. 
Justice Douglas's concurrence suggested that courts should accord a defendant's preference of remedies considerable, if not controlling, weight, ${ }^{36}$ as a prosecutor's breach of a plea bargain implicates the defendant's fundamental rights. ${ }^{37}$ At the same time, Justice Douglas recognized, as did the majority, that the state court's choice of an appropriate remedy should depend on the circumstances in each case.

Justices Marshall, Brennan and Stewart, concurring in part and dissenting im part, argued that Santobello should have been allowed to withdraw his plea as he requested, ${ }^{38}$ but suggested that the choice of remedy should be left to the defendant. ${ }^{39}$ They agreed with Justice Douglas that a defendant's preference deserved considerable, if not controlling weight. ${ }^{40}$ Thus, while a majority of the Santobello Court asserted the need for a flexible, case-by-case determination of the appropriate remedy for a broken plea bargam, ${ }^{41}$ a separate inajority of the seven-meinber Court ${ }^{42}$ apparently believed that the controlling criterion for this choice should be the defendant's preference. ${ }^{43}$

Three years after Santobello, the California Supreme Court, in People v. Johnson, ${ }^{44}$ limited the availability of specific performance as a remedy for broken plea bargains by refusing to enforce a bargain obtamed through the defendant's imisrepresentations to the trial court. The defendant had suggested that because the trial court failed to inform limi of his rights under Penal Code Section $1192.5,{ }^{45}$ lie should have the option of enforcing the bargain or claiming his statutory right to withdraw his guilty plea. The California court rejected this argument, commenting that the defendant's imisrepresentations reinforced its reluctance to create a right to specific performance of a plea bargain im all cases where a trial judge failed to advise a defendant of his section 1192.5 rights. Instead, the court read the section as vesting broad

\footnotetext{
36. Id. at $\mathbf{2 6 7}$ (Douglas, J., concurring).

37. Id.

38. Id. at 267-68 (Marshall, J., concurring in part and dissenting in part).

39. Id.

40. Id. at $268 \mathrm{n} . *$.

41. Id. at 263 (opinion of the Court); id. at 267 (Douglas, J., concurring).

42. Id. at 267 (Douglas, J., concurring); id. at 268 (Marshall, J., concurring in part and dissenting in part) (joined by Brennan and Stewart, JJ.).

43. Id. at $268 \mathrm{n} .{ }^{*}$ (Marshall, J., concurring in part and dissenting in part) ("[A] inajority of the Court appears to believe that in cases like these, where the defendant seeks to vacate the plea, that relief should generally be granted.") While Justice Marshall noted that "it inay be appropriate to permit the defendant to enforce the plea bargain," id. at 268, he favored withdrawal of Santobello's plea, as that remedy was sought by the defendant. In Pcople v. Kaanehe, 19 Cal. 3d at 14-15, 559 P.2d at 1037, 163 Cal. Rptr. at 418, the California court seems to have adopted a similar approach. In Kaanehe, where the state sought specific perfornance of the bargain, the court held that the prosecutor's "glaring" breach entitled the defendant to his choice of remedies. See infra text accoinpanying notes 47-49.
}

44. $10 \mathrm{Cal} .3 \mathrm{~d} 868,519$ P.2d 604, 112 Cal. Rptr. 556 (1974).

45. See supra text accoinpanying note 25 . 
discretion in the trial judge to withdraw prior approval of a negotiated plea, ${ }^{46}$ thus implying that it would be unwilling to enforce a remedy which interfered with this discretion.

In People v. Kaanehe, ${ }^{47}$ the supreme court ordered that the defendant be allowed to choose between specific performance and withdrawal of his plea. ${ }^{48}$ The defendant in Kaanehe had agreed to plead guilty in exchange for the prosecutor's promise not to inake a sentencing recoinmendation. Although the prosecutor breached his promise, the trial court sentenced the defendant to prison without allowing him to withdraw his guilty plea. The supreine court held that because the remedy sought by the prosecution, specific performance, would not have coinpletely undone the harm caused by the prosecutor's "glaring" breach, the defendant should have been given the option of either specific performance or withdrawal of the plea. The court noted that specific enforcement of a plea bargain between the prosecution and the defense would not be allowed absent very special circumstances, as a prosecutor and a defendant should not be able to bind a trial court and limit its sentencing discretion. In this case, the special circumstances doctrine was held to be inapplicable, because enforcenent of the terms of the bargain would not have restricted the trial court's sentencing discretion. ${ }^{49}$

Thus, in California, the flexibility granted to the state courts in Santobello has been interpreted so as to give priority to preserving trial court sentencing discretion at the expense of the defendant's interest in having a choice of remedy for breach of a plea bargain. A defendant who seeks to have such a choice honored must demonstrate the existence of special circumstances, or show that the trial judge's discretion is not restricted by the remedy granted.

The California Supreme Court, however, has not yet articulated a standard to be used in finding the existence of special circumstances. Furtherniore, while the special circumstances doctrine preserves the trial court's sentencing discretion in inost cases, it is misapplied when the trial judge himself inakes a plea bargain commitment and then repudiates it in the course of exercising his sentencing discretion.

46. $10 \mathrm{Cal} .3 \mathrm{~d}$ at 873,519 P.2d at $607,112 \mathrm{Cal}$. Rptr. at 559.

47. 19 Cal. 3d 1, 559 P.2d 1028, 136 Cal. Rptr. 409 (1977).

48. Id at 14-15, 559 P.2d at 1037, 136 Cal. Rptr. at 418 (citing concurring and dissenting opinions in Santobello). See supra note 43.

49. Unlike Johnson, allowing specific performance in Kaanehe would not have bound the trial court's sentencing discretion, since the trial judge in Kaanehe had approved of the bargain at all times. See infra note 56. 


\section{III \\ ANALYSIS \\ A. Judicial Commitment and Special Circumstances}

The Calloway court's failure to recognize the significance of the distimction between plea bargain commitments made by prosecutors and plea bargain commitments made by judges is contrary to the constitutional requirement that guilty pleas be imtelligently made. A defendant's perception of the identity and authority of the party making such a commitment is an important part of his imtelligent understanding of the consequences of the plea requircd by Brady $v$. United States, ${ }^{50}$ and of his subsequent conduct based on that understanding. Because a judge is an authoritative figure im charge of sentencing, a defendant who perceives that a judge has made a plea bargain commitment is justified in believing that the commitment will be honored and in actimg accordingly. ${ }^{51}$

When a trial judge himself makes a plea bargain commitment, he departs significantly from typical plea bargain approval procedures. This can influence a defendant's understanding of the consequences of his plea. ${ }^{52}$ Defendants who negotiate pleas with prosecutors realize that the prosecutor's freedom of negotiation, and thus the strength of his commitment, is limited by the requirement that the resultimg plea be approved by the trial judge. At the saine time, the trial judge's role is generally limited to either approval or disapproval of the bargains.

Most judges will limit their role by insulating thenselves from the negotiating process, or by making clear that their sentencing discretion cannot be waived. A trial judge who disregards these conventions will in many cases create an expectation that sentencing discretion will be waived. This appears to lave occurred in Calloway. The trial judge expressly limited his own sentencing discrction by telling the defendant he would not be sent to prison, and the defendant reasonably believed that the judge would keep his promise.

Defendants' perceptions of the judiciary's fairness and impartiality also affect their expectations of judges' promises. A prosecutor, for example, is held to a standard of fair conduct in the plea negotiation pro-

50. 397 U.S. at 748.

51. See People v. Delles, 69 Cal. 2d 906, 447 P.2d 629, 73 Cal. Rptr. 389 (1968) (defendant entitled to withdraw plea made in reliance on promise of trial judge, "an apparently authoritative and reliable public official."); People v. Dixon, 103 Mich. App. 518, 303 N.W.2d 32 (1981) (defendant entitled to choice of remedy for breacl of judge-made bargain; because sentencing authority is the exclusive province of the judiciary, a judge's promise regarding sentencing is enforceable by the defendant).

52. While judges are frequently active in the plea bargaining process, they rarely make direct promises to a defendant regarding sentencing. See People v. Superior Court (Smith), $82 \mathrm{Cal}$. App. 3d 909, 914, 147 Cal. Rptr. 554, 557 (2d Dist. 1978). 
cess, ${ }^{53}$ but both defense attorneys and criminal defendants tend to view his actions, promises, and commitments with a degree of skepticism in light of his traditional adversarial role in the criminal justice system. A judge, however, can be perceived as playing a more impartial and objective role, in keeping with his duties as the representative of a judicial system committed to these values. If faith in the impartiality and objectivity of the judiciary is to be promoted, a judge should be lield to a standard at least as strict as that to which prosecutors are held.

Calloway illustrates the impact that a trial judge's conduct can liave on a defendant's reasonable understanding of the consequence of his guilty plea. The trial judge in Calloway carefully explaimed the significance and purpose of the 90-day diagnostic confinement period, and expressly outlined the sentencing alternatives which would be open to the court when the defendant returned for sentencing. ${ }^{54} \mathrm{He}$ concluded by telling the defendant he would not be sent to state prison, and said nothing that would have indicated his commitment was revocable. The defendant imdicated that he understood the judge's statement, which he could reasonably have interpreted as an unconditional promise by the judge to limit his sentencing discretion. ${ }^{55}$ Calloway's acceptance of the bargain and of 90 days of diagnostic confinement indicate that he did interpret the statement in this way.

These factors in Calloway are unusual in plea bargaining situations. Where they do exist, however, a court should find special circumstances justifying specific performance of the bargain. The judge's mvolvement went beyond the traditional noncommittal approval of the plea bargain contemplated both by People v. Johnson and by Penal Code section 1192.5. His behavior created a reasonable expectation im the defendant that the commitment would be honored, an expectation which was enhanced by the special position occupied by the trial judge in the criminal justice system. The harm to the judiciary's image of integrity and impartiality which would be caused by allowing judges to break express commitments constituted a further justification for a finding of special circumstances in Calloway.

The court's rigid imterpretation of the special circumstances doctrine cannot be squared with Santobello's recognition of the desirability of a flexible, individualized approach to the determination of a proper remedy. Under Calloway, a court may reject the remedy of specific

53. See, e.g., Correale v. United States, 479 F.2d 944 (1st Cir. 1973).

54. See supra note 14.

55. See, e.g., Brady v. United States, 397 U.S. 742 (1969). Implicit in the concept of plea bargaining is the idea that an agent of the State may make a personal commitment to bind his own actions at trial. Cf. People v. Delles, 69 Cal. 2d 906, 910, 447 P.2d 629, 632, 73 Cal. Rptr. 389, 392 (1968) (relief granted for reliance on judge's promise as that of "an apparently authoritive and reliable public official"). 
performance on the basis of a single triggering factor, restriction of the trial court's sentencing discretion, without considering other relevant circumstances such as the defendant's detrimental reliance or the participation of the judge in the negotiation process. ${ }^{56}$

\section{B. Noncompensable Detrimental Reliance as a Special Circumstance}

A defendant's detrimental reliance on a judge's promise should constitute a special circumstance requiring specific performance of a plea bargain when withdrawal of the defendant's guilty plea is inadequate to return him to the status quo ante. Any other remedy would place an unfair burden on the defendant in a situation which is essentially a mutual exchange of benefits. ${ }^{57}$

In determining the fairness of a plea bargain agreement, courts often draw analogies from the law of contract. ${ }^{58}$ Such an analogy is helpful here. Calloway's coinplete perfornance of his part of the plea bargain created an enforceable unilateral contract between him and the trial judge. ${ }^{59}$ In general, a contract will be specifically enforced in those cases where money damages are inadequate compensation for the injury caused by the breach. ${ }^{60}$ If Calloway were to be found innocent of violating his probation, noney damages would be inadequate compensation for his wrongful incarceration. ${ }^{61}$ Moreover, they are madequate where the thing bargaimed for is unique. ${ }^{62}$ The subject inatter of

56. The Kaanehe court was unwilling to find special circumstances when enforcing the agreement between the defendant and the prosecution would limit the trial court's sentencing discretion. See supra text accompanying note 49 . However, a situation such as that in Calloway, in which the trial judge himself makes a promise, does not involve limitation of the trial court's sentencing discretion. It is, instead, an exercise of that discretion, in which the trial judge inakes a choice that the defendant will not be subject to certain types of sentences, such as confinement to state prison. This is no less an exercise of discretion than a judge's final decision to give the defendant one sentence, at the preclusion of all others. Because the trial judge's promise is an exercise of his sentencing discretion, specific performance of the promise would ouly be a means of carrying out that discretion, and not a limitation of it. Kaanehe would therefore not preclude finding special circumstances when a trial judge breaches his own promise. $C$. People v. Superior Court (Smith), 82 Cal. App. 3d at 915-16, 147 Cal. Rptr. at 558 (trial judge may indicate what sentence he will impose if a given set of facts is confirmed).

57. See Brady v. Umited States, 397 U.S. 742,753 (1969).

58. E.g., Blackledge v. Allison, 431 U.S. 63, 75 n.6 (1977); Palermo v. Warden, 545 F.2d 286 (2d Cir. 1976).

59. See J. Calamari \& J. Perillo, The Law of Contracts $\$ \$ 4-15$ (2d ed. 1977). Both prosecution and defense acknowledged that an enforceable agreement existed. $29 \mathrm{Cal}$. $3 \mathrm{~d}$ at 668 , 631 P.2d at 30, 175 Cal. Rptr. at 596.

60. 58 CAL. JUR. 3D Specific Performance § 5 (1980).

61. Although cash damages are sometimes awarded for wrongful inprisonment, eourts do not maintain that cash is adequate compensation for time wrongfully spent in prison. Cash damages are better than no remedy at all, and are only a means of making the best of a bad situation. See, e.g., Note, Compensation of Persons Erroneously Confined by the State, 118 U. PA. L. REV. 1091, 1097 (1970).

62. See, e.g., J. Calamari \& J. Perillo, supra note 59, \$§ 16-2, -3. 
Calloway's agreement, a judge's promise affecting Calloway's liberty or his place of mcarceration, should be considered unique.

In some situations, a remedy of rescission might be appropriate where the defendant can be restored to the status quo ante, as where there is no detriment in the defendant's reliance. Where there is detriment, a special circumstance justifying specific performance should exist. By holding that noncompensable detrimental reliance is not a special circumstance, the Calloway court implies that the risk of such harm to the defendant is simply a normal aspect of the plea bargaining process. When the defendant is the only party who is subject to risk, the fairness which the Santobello Court suggested is crucial to tlie legitimacy of the plea bargaining process is strained. ${ }^{63}$

\section{Application of the Plain Meaning Rule}

The existence of special circumstances in future plea bargaining cases will depend on low plea bargains made by judges are interpreted. This interpretation should turn on what a reasonable person in the defendant's position would liave believed liad occurred, especially because the defendant's guilty plea entailed the waiver of significant constitutional rights. ${ }^{64}$ The "plain meaning rule" of contract law, while not directly applicable in plea bargain situations, nevertheless offers a helpful analogy in this regard. ${ }^{65}$

The plain meaning rule provides that where one party knew or had reason to know of an annbiguity in a contract, and the otlier party did not, the ambiguity will be interpreted in favor of the latter party. ${ }^{66}$ In Calloway, the trial judge either knew or had reason to know of the ambiguous nature of his commitment. There is no indication that the defendant had such knowledge. If the terms of the bargain were presented to the defendant in a manner whiclı misled him as to the consequences of the bargain, the defendant should not be held respon-

63. See supra text accompanying note 33 .

64. Cf. Dukes v. Warden, 406 U.S. 250, 258 (1972) (Stewart, J., concurring) (waiver of rights surrounding trial called "perhaps the most devastating waiver possible under our Constitution."); Brady v. Umited States, 397 U.S. 742, 748 (1970); Boykin v. Alabama, 395 U.S. 238, 243-244 (1969).

65. Cooper v. United States, 594 F.2d 12 (4th Cir. 1979), held that the constitutional right to fairness in plea bargaining was wider in scope than the rights provided under contract law. However, the court's discussion of the specific and unambiguous nature of the plea bargain at issue, $i d$. at 16-17, illustrates the usefulness of contract doctrine in resolving plea bargaining disputes. See supra note 58.

66. See, e.g., Restatement (Second) of Contracts $\$ 201$ (1981); J. Calamari \& J. PeRILlo, supra note 59, \$§ 3-10. Cf. People v. Castro, 42 Cal. App. 3d 960, 965, 117 Cal. Rptr. 295, 298 (4th Dist. 1974) ("the terms of a plea bargain inust be gathered froin what was said and done at the time the bargain was made . . . ."). 
sible for his reasonable misinterpretation. ${ }^{67}$ Such a result would be contrary to both the "intelligence" requirements of Brady 68 and the Santobello requirement that the plea bargaining process be conducted fairly. ${ }^{69}$ Application of the plain meaning rule would fulfill both requirements, and would encourage greater clarity in a judge's formulation of the terms of the plea bargain.

\section{Calloway's Presumption of Guilt}

In considerimg the fairness of withdrawal as a remedy, the Calloway court implicitly presumed that the defendant would eventually be found to have violated the terms of his probation. The court asserted that withdrawal of the plea would be fair because the defendant would receive an appropriate credit for his diagnostic confinement if sentenced to a term of incarceration following withdrawal of his guilty plea. The court's justification of the fairness of its ruling on the grounds of an event which was not certain to occur demes the defendant the fundamental protection provided by the doctrine that a defendant's innocence is presumed until his guilt if proven. ${ }^{70}$

A presumption of Calloway's guilt is evident in the court's suggestion that withdrawal of the plea was an appropriate remedy because of the defendant's inadequate performance on probation. ${ }^{71}$ By basing its decision on conduct of which the defendant was only accused, the court misconstrued the Santobello requirement that the focus of analysis be on fairness in securing agreement between the accused and the prosecutor $^{72}$ or, a fortiori, between the accused and the trial judge. Concentrating on the defendant's behavior prior to the plea bargain agreement allowed the Calloway court to use an impermissible criterion, presumption of guilt, to determine that special circumstances did not exist in the defendant's case. A logical extension of the Calloway court's reasoning on this point would lead to the conclusion that any criminal defendant could fairly be denied specific performance of a plea bargain solely on the basis of alleged wrongdoing, irrespective of whether there was detrimental rehance.

67. Cf. Santobello v. New York, 404 U.S. at 262 (inadvertent breach by government held not to negate defendant's right to remedy).

68. 397 U.S. at 748, 756-58. See also Westen \& Westin, A Constitutional Law of Remedies for Broken Plea Bargains, 66 CALIF. L. Rev. 471, $506 \mathrm{n} .130$ (1978) ("[]t would be irrational to require that the defendant be advised of the consequences of conviction, and yet permit the advice to be maccurate.")

69. 404 U.S. at 261.

70. See, e.g., B. Witkin, California Crimmal Procedure $\$ 339$ (1963); B. Witkin, CaLIFORNIA EVIDENCE \& 202 (1966).

71. 29 Cal. 3d at 672, 631 P.2d at 33, 175 Cal. Rptr. at 599.

72. 404 U.S. at 261. 
The court's failure to presume that Calloway was innocent also raises the possibility that he will not have an appropriate remedy for wrongful imprisonment if he is subsequently found innocent of the substantive charge of probation violation. Under California law, a trial judge is immune from civil suits arising from the performance of his duties. ${ }^{73}$ Even if Calloway could sue for wrongful imprisonment, the inoney damages which he might recover in such a suit would probably not be regarded as adequate compensation for a wrongful deprivation of freedom. ${ }^{74}$ Money damages im such situations are simply the best remedy that society can provide. It is, moreover, poor policy to allow a defendant to be incarcerated on a presumption of guilt on the justification that if this presumption is later proven wrong, the defendant may be "paid off" and returned to the status quo ante. Where a defendant has gone to prison in reliance on a breached plea bargain, the better solution to this problem is to enforce the bargain.

\section{E. Calloway's Implications for the Integrity of the Plea Bargaining System}

Judging plea bargains by the relaxed standards of Calloway threatens the integrity and credibility of the plea bargaining system as perceived by participants in the system and by the public. ${ }^{75}$ Calloway provides no mcentives for judges to exercise care in either approving plea bargains or im making plea bargam commitments. In effect, it tells trial judges that they can almost never be sanctioned for breaching their own plea bargain commitments, as the detrimental reliance which was insufficient to establislı special circumstances im Calloway will not be present in most cases.

This is more than a theoretical problein. A trial judge, for example, could be reluctant to give effect to pleas whicli would result in the

73. CaL Gov'T CODE $\$ 820.2$ (West 1980) (government employee not liable for injury resulting from act or omission that was "the result of the exercise of the discretion vested in him. . . ."). See J.A. Meyers \& Co. v. Los Angeles County Probation Dep’t, 78 Cal. App. 3d 309, 144 Cal. Rptr. 186 (2d Dist. 1978).

74. See Foote, Tort Remedies for Police Violations of Individual Rights, 39 MINN. L. REv. 493, 497 (1955).

75. See Cooper v. United States, 594 F.2d at 17 ("Conduct by government prosecutors that in the marketplace would constitute breach of contract or give rise to promissory estoppel will practically always reflect constitutionally unfair conduct in transactions betwecn sovereign and citizen in inatters of liberty and punishment."). Moreover:

Common intuitions suggest that it is fundamentally unfair for the state to create and then destroy a defendant's expectations. We generally assume that people ought to keep their promises, at least in the absence of unusual circumstances. . . . Because of the extraordinary power of the state and the critical nature of promises concerning criminal consequences, this obligation applies with special force to representatives of the state who enter into plea agrcements with individual defendants.

Westen \& Westin, supra note 68, at 524. 
release of defendants perceived as potentially dangerous. If the defendant is limited to the remedy of withdrawal, the judge would not need to abide by his own terms if it later proved mexpedient to do so. In this context, a judge who makes a bargain without first reviewing all the available evidence relevant to its propriety ${ }^{76}$ may avoid any possible adverse consequences by breaching the agreement.

A holding that allows a trial judge to make casual, easily breached promises encourages defendants and the general public to perceive that judicial decisions relating to plea bargains do not result froin careful, responsible deliberation. This is an inappropriate image for "an essential component of the administration of justice."77 By requiring fulfillment of the trial judge's commitment in Calloway, the court could have encouraged both actual and perceived judicial responsibility in the plea bargaining process.

On the other hand, a rule which would put trial judges on notice that they will be held to the terms of their bargains ${ }^{78}$ would force judges to take greater care to see that those terms are justified ${ }^{79}$ A selfinterested busmessinan is routmely held to such standards; ${ }^{80}$ it is even more important that the judge, as the personification of the fairness of the judicial system, be held to a standard at least as strict. ${ }^{81}$

\section{CONCLUSION}

This Note has argued that Calloway's rigid interpretation of the special circumstances doctrine establishes a firm presumption against specific performance of a breached judicial plea bargain im Califorma. Specific performance should have been granted in Calloway because of the defendant's perception of the judge's authority, because the defendant detrimentally rehed on the judge's promise by agreeing to 90 days of confinement, and because the ambiguity in the bargain was created by the judge and should therefore have been interpreted in favor of the

76. This problem is particularly pronounced in Calloway, where, prior to the agreement, the trial judge possessed but evidently did not read four supplementary probation reports recommending a prison sentence for the defendant. See supra note 15.

77. Santobello v. New York, 404 U.S. at 260.

78. The alternative, a disclaimer similar to that required by CAL. Penal Code $\$ 1192.5$ (West Supp. 1981), see supra text accompanying note 25, could be accomplished by legislation.

79. See 17 Stan. L. Rev. 316, 320 (1965).

80. Westen \& Westin, supra note 68, at 524. Cf. Tigar, The Supreme Court, 1969 TermForeword: Waiver of Constitutional Rights: Disquiet in the Citadel, 84 HaRv. L. REv. 1, 20 (1970) ("Judges who would not hesitate to condemn a furniture dealer who preyed on the ignorance of his customers and exploited a superior bargaining position will routinely approve the plea bargain that results from negotiations between the state and an uninformed, powerless defendant.") (This observation was made prior to Santobello.)

81. See Cooper v. United States, 594 F.2d at 16-17 (constitutional right to fairness in plea bargaining held to be wider in scope than that defined by contract law). 
defendant. Moreover, the court's reasons for denying specific performance presumed the defendant's guilt. The court's holding bypassed consideration of the individual circumstances of the case, drastically restricted the flexibility of reinedy required by Santobello, and could have the ultimate effect of lowering public perceptions of the judiciary's fairness.

The state legislature could provide a solution to the problein presented in Calloway by enacting a statute codifying the trial judge's role in plea bargaining. A legislative determination that the judge may take no part in fashioning the bargam and inay inake no personal commitments to the defendant would put all parties on notice that the judge's role in the bargaining process is limited to that described in section 1192.5 of the California Penal Code. Such a statute would remove all possible misunderstandings surrounding a judge's statements regarding sentencing, yet would preserve his sentencing discretion. Moreover, the statute would codify current case law which expressly separates the roles of trial judge and prosecutor in the plea bargaining process.

Alternatively, the legislature or the courts could limit Calloway by making clear that when a judge breaches his own plea bargain agreement, special circumstances will exist, and the defendant will be given the option of specific performance or withdrawal of his plea. This would remove the inequities of the Calloway decision. It would also put judges on notice that their plea bargains must be carefully considered as they will be held strictly accountable to the ternis of those bargains. Adoption of this solution, or of the solution which renoves judges froin plea bargain negotiations, would help ensure that plea bargains are fair and fit the circumstances of each individual case.

Paul A.S. Spiegel*

* A.B. 1979, University of California, Berkeley; third year student, Boalt Hall School of Law, University of California, Berkeley. 